\title{
Suuntana sivistys
}

\author{
Eero Ojanen 2000 \\ Onko meillä malttia \\ sivistykseen? Tilaa \\ sivistykselle -sarja. \\ KANSANVALISTUSSEURA
}

Ulla Koivunen (toim.)

2001. Kokonaisuutta

etsimässä. På jakt

efter helheten.

KANSANVALISTUSSEURA

\section{Snellmanin tiedetään}

päättäneen hengen olemusta

käsitelleen ja oppilaiden koko

elämänkulkuun vaikuttaneen

luentosarjansa ajattelulleen us-

kollisena vaatimattomaan

huomautukseen: tulevina ai-

koina nämä samat totuudet

löydetään toisin käsittein.

Eero Ojanen on ottanut teh-

täväkseen - snellmanilaiseen ja

idealistiseen ajatteluun juur-

tumisensa tunnustaen - ku-

vata sivistys nykykäsittein. Ai-

don dialektikon tavoin hän

antaa sivistyksen käsitteen

kehkeytyä täyteen rikkauteen-

sa vastakohtiensa kautta ja nii-

den jännitteessä.

\section{Onnistuuko Ojanen}

tässä niin, että sivistyksestä

tulisi nykyihmisen elämänkul- kuun vaikuttava voima? Huomaan vastaavani kysymykseen vähän epäröiden. Sivistyksen idea on hautautunut niin monen ajatuskerrostuman alle, että sen elävöittäminen on pitkä työ. Mutta Ojasen käsittely on erinomainen johdatus jokaiselle, joka haluaa paneutua sivistyksen olemukseen ja ottaa kantaakseen siitä aiheutuvan vaivan.

\section{Kirjoittaja paikallistaa} sivistyksen ideaa suhteessa muihin elämänilmiöihin. Snellmanille sivistys oli myös maan taloudellisen nousun edellytys. Tässä Ojanen sanoo tietoisesti poikkeavansa Snellmanin linjasta. Ojaselle tekniikan mittelöin käytävä kansainvälinen taloudellinen kilpailu on nykyajan sotaa. Ja tunnetusti väkivalloin Suomi ei voi mitään tehdä, sivistyksen voima on sen ainoa pelastus. Ojasen käsittelyssä sivistys saa askeesin sävyn. Hän marssittaa heiveröiset sivistyksen voimat taisteluun taloutta, tekniikkaa ja kilpailua vastaan. Näin voi tehdä ja joistakin näkökulmista, erityisesti ekologisesta, se voi olla välttämätöntäkin. Mutta asian voi nähdä myös toisin.

\section{Laaja-alainen sivistys,} johon hyvin mahtuu myös tekninen sivistys, on kansakunnan ainoa turva avoimen kilpailun maailmassa, jossa osaaminen on korvannut aseet ja jossa jälkeen jääminen merkitsee paluuta kehitysmaaksi. Tekemällä nörtit ja nokialaiset sivistyksen vihollisiksi heidät ajetaan pöyhkeilemään sivistymättömyydellään, ilmiö josta siitäkin on jo esimerkkejä. Ongelmana ei ole tekniikka eikä kilpailukaan, vaan se, että ne korostuvat yksipuolisesti monine hankaline seurauksineen. Sivistys alkaa olla elämänvälttämättömyys.

\section{Katsoo asiaa kummalta} kannalta tahansa, Ojanen tekee riemastuttavan keksinnön. Yhtä itsestään selvästi kuin olemme tottuneet arvioimaan erilaisten päätösten ympäristövaikutuksia meidän pitäisi arvioida niiden sivistysvaikutuksia. Ensituntumalta ajatus tuntuu mahdottomalta toteuttaa, mutta juuri siinä on sen viehätys. Tällainen arviointi olisi haaste, joka askel 
askeleelta tuottaisi jäsentyneempää käsitystä niistä hyvän elämän ehdoista, joita kuvaamaan sivistyksen käsite on luotu. - Olisi tärkeää, että Ojanen antaisi edelleen henkensä askaroida sivistyksen tulkinnassa käsittein, jotka avautuvat nykyihmiselle.

$$
* * * *
$$

\section{Kansanopisto on yksi} sivistyksen kehto, jolle juuri siksi on myös lainsäädännössä suotu erikoisasema. Sen ylläpitäminen edellyttää jatkuvaa kansanopiston sisäistä kehittämistä. Jos jollakulla on mielessä epäilevä kysymys siitä, onko kansanopisto sisäisesti hengissä, voi helpottuneena vastata, että ainakin LänsiSuomessa on. "Kokonaisuutta etsimässä" tiivistää 16 artikkelina tulokset seitsemän läntisen kansanopiston kokonaisvaltaista oppimista koskeneesta hankkeesta, jonka tarkoituksena on selventää kansanopiston erityislaatua.

\section{Kansanopisto on}

muuttunut ympäristön paineessa formaaleja opintoja tarjoavaksi oppilaitokseksi, mutta sen ei tarvitse merkitä ominaislaadun katoamista. Ratkaistavaksi tulee Paula Ilénin sanoin yhtälö, jossa yhdistetään avoimen yliopiston opinnot (tai muut arvosanat/ tutkinnot), kansanopistoopinnot ja yhteisöllisyys. Nonakalaisesti sanottuna kirjoittajat ovat vakuuttuneita siitä, että heidän käsissään on arvokasta kansanopiston hiljaista tietoa. Juuri sen tiedon varassa syksyinen arka, syrjään ja itseensä vetäytynyt, vaikeasti puhuva ja yhä useammin myös tavalla tai toisella ongelmainen nuori muuttuu reippaaksi, sosiaaliseksi ja it- seään ilmaisevaksi ihmiseksi. Jollakin tavoin tämä tieto kytkeytyy internaattiyhteisön ympärille kytkeytyvään kansanopistopedagogiikkaan.

\section{Miten saada tämä}

hiljainen tieto eksplisiittiseksi tiedoksi ja muotoon, jossa se on mahdollista kertoa myös ulospäin? Viime vuosien kasvatustiede ei ole juurikaan tarjonnut käsitteitä tähän tarkoitukseen. Kirjassa sovelletaan useitakin kuvausjärjestelmiä, valaisevasti, mutta ei varmaan vielä tyhjentävästi. Silti kirja on tärkeä virstanpylväs. Projektin aikana jokainen kirjoittaja on ratkaissut oman identiteettinsä kansanopiston opettajana tai muun henkilöstön jäsenenä, mikä sekin on hienosti mukana teoksessa. Voin hyvin kuvitella, että kirja on arvokas jokaiselle uudelle työntekijälle portaana kansanopiston erityiseen maailmaan.

\section{Artikkeleista mieleen}

jäävin oli se, missä Eeva-Kaisa Lemmetyinen piirtää kansanopisto-opiskelijan muotokuvia. Ne osoittivat, miten erilaisia opiskelijat ovat ja miten heitä ei voi kohdata millään kaavalla. Jokainen tarvitsee henkilökohtaisen oppimissuunnitelmansa, joka vahvistaa juuri hänen Elämänkompetenssiaan. Sen, että lähtökohtana on yksilö, ei tarvitse olla vastoin kansanopiston yhteisöllistä perusluonnetta.

\section{Kansanopisto syntyi ja} varttui rinnan suurten kiinteiden kansanliikkeiden kanssa. Nyt olemme eläneet ajan, jona ihminen on rimpuillut itsensä irti sitovasta yhteisöllisyydestä. Näemme myös sen tuomat haitat. Oletan, ettei ihminen jatkossakaan menetä saavuttamaansa yksilöllisyyttä, mutta hän oppii uudella tavalla käyttämään yhteisöjä yksilöllisen elämänsuunnitelmansa osana. Silloittavaan yhteisöllisyyteen on kova tarve ja sen oppimiseen kansanopisto on poikkeuksellinen mahdollisuus. Sillä kansanopiston ydin on yhteisöllisyys ja dialogi, yhtenä keinona internaatti mutta mahdollinen myös muin tavoin, esimerkiksi yhteisöllisyysopintoina kuten Paasikivi-opistossa.

\section{Joitakin asioita jäin}

kirjasta kaipaamaan. Yksi niistä oli sosiaalinen pääoma; luottamuksesta ja vastavuoroisuudesta käyty keskustelu tekisi kansanopistopohdinnalle terää. Lähteistä en löytänyt Pauli Siljanderin tutkimusta N. Fr. S. Grundtvigin sivistysnäkemyksestä ja kansanopiston tehtävästä. Sitäkin kannattaisi edelleen lukea. Kirjassa oli Eivor Huldénin erinomainen artikkeli loppuunpalamisesta, mutta ei johtopäätöstä, jota Ove Korsgaard on suosittanut oppilaspulaa kokeville Tanskan kansanopistoille. Ainakin joissakin kansanopistoissa kannattaisi nostaa opiskelijoiden keski-ikää 20-30 vuodella. Kipeimmin kansanopistomiljöön herättämää henkistä ja sosiaalista pääomaa juuri nyt tarvitsevat ne 165000 suomalaista, jotka kärsivät vakavasta uupumuksesta.

\section{Uusimmillakin}

toimituksillaan Kansanvalistusseurasta on tullut sivistystä herättävä ja virittävä kustantaja. Kyse on tärkeästä tehtävästä suomalaisen sivistysliikkeen palveluksessa.

Seppo Niemelä 